\title{
Sero-epidemiology and risk factors of syphilis in Makassar, Indonesia
}

\author{
Maryam KUSUMAWATY' ${ }^{*}$, Khairuddin DJAWAD ${ }^{1}$, Muh NASRUM MASSI ${ }^{2}$, Andi Muhammad \\ $\mathrm{ADAM}^{1}$, Siswanto WAHAB ${ }^{1}$, Burhanuddin BAHAR $^{3}$ \\ 1Department of Dermatology and Venereology Faculty of Medicine, Hasanuddin University, Makassar, Indonesia \\ ${ }^{2}$ Department of Microbiology Faculty of Medicine, Hasanuddin University, Makassar Indonesia \\ ${ }^{3}$ Faculty of Public Health, Hasanuddin University, Makassar, Indonesia \\ *Correspondence: Maryam Kusumawaty, E-mail: maryamhusni1@yahoo.com \\ UDC 616.972-036.22-07(594) \\ UDC 616.988:578.828HIV-036.22(594)
}

\begin{abstract}
Introduction. Syphilis is an infectious disease caused by Treponema pallidum spirochete and is mainly transmitted by sexual contact. Syphilis has the potential to cause serious complications and is closely related to human immunodeficiency virus (HIV) infection thus making syphilis still a major public health problem. In Indonesia, surveys of high-risk populations in 2007 and 2011 reported an increase in the prevalence of syphilis, especially in men who have sexual relationships with other men (MSM). Moreover, studies have described risk factors for HIV transmission including MSM, heterosexual contacts, Intravenous (IV) drug use, and infected partners. Objectives. To assess the epidemiological aspects and risk factors for syphilis in Makassar, as well as the correlation with a coinfection of other sexually transmitted infections. Material and Methods. This study is a multi-centre cross-sectional descriptive study with consecutive sampling. We evaluated cases for eligibility by confirming the diagnosis based on the serological result using rapid plasma reagin assay (RPR), Treponema pallidum haemagglutination (TPHA), and HIV screening kit. The cases were analyzed based on epidemiological features, risk factors and clinical findings, coinfection with other sexually transmitted infection (ST), and stadium of the disease. Results. A total of 79 serologically confirmed syphilis cases were collected between January 2017 and December 2018 in Makassar, the capital city of South Sulawesi province in Indonesia. Of the 63 male subjects (79.7\%), 38 (48.1\%) were homosexual/MSM, and in 41 cases of HIV-infected subjects, 25 (60.9\%) of them were also MSM. Conclusion. Our study showed there was a significant correlation between syphilis and an increased risk of HIV transmission in MSM groups. The higher number of cases of syphilis and HIV co-infection among MSM can increase transmission of both infections and should be considered a major risk factor for syphilis in Makassar.
\end{abstract}

Key words: Syphilis Serodiagnosis; Risk Factors; Syphilis; Seroepidemiologic Studies; Sexually Transmitted Diseases; Homosexuality, Male; Indonesia

\section{Introduction}

Syphilis is an infectious disease caused by Treponema pallidum spirochete and is mainly transmitted by sexual contact (1). Syphilis is divided into several stages, namely the primary, secondary and latent stage, in which clinical manifestations can develop from one stage to another if no appropriate treatment is given to the patient. Syphilis has the potential to cause serious complications and is closely related to HIV infection thus making syphilis still a major public health problem (2). Syphilis initially emerged in the 15th century, and its prevalence has declined by the 20th century. However, over the last few decades, the prevalence increased again in American countries, Europe and Asia $(3,4)$. Studies in Australia reported an increase in the prevalence of syphilis, especially among MSM, although now syphilis is also increasing in the general population, especially among adolescents and young adults $(5,6)$. In Indonesia, surveys of high-risk populations were carried out by the Surveilans Terpadu Biologi Perilaku (STBP) in 2007 and 2011 and reported an increase in the prevalence of syphilis, especially in MSM with the prevalence of $4 \%$ to $13 \%$. The highest prevalence of syphilis was 
found in MSM populations, namely a total of 28\% (7). Studies in the United States described that MSM (51\%) was the most reported risk factor for HIV transmission, followed by high-risk heterosexual contacts (14\%), IV drug user (9\%), and MSM IV drug user (7\%). They also stated that MSM living with HIV are 5 times more prone to syphilis co-infection, compared with heterosexual men with HIV (8). Serological tests are now the mainstay of workup diagnostics for syphilis (9). Antibody measurements are important for screening and diagnosis of syphilis. Two categories of antibodies are called "Nontreponemal" which are directed against phospholipid, and "treponemal" which is directed against the Treponema pallidum polypeptide used for this purpose. Non-treponemal antibodies are detected by the Rapid Plasma Reagin (RPR) test, the Venereal Disease Research Laboratory (VDRL) test, and the Toluidine Red Unheated Serum test (TRUST). Treponemal antibodies are detected by immunofluorescence in Fluorescent Treponemal Antibody Absorption tests (FTAABS) or by agglutination in Treponema pallidum Hemagglutination test (TPHA) or Treponema pallidum Particle Agglutination Assay (TP-PA) (10). In this study, the serological examination used was RPR and TPHA.

\section{Material and Methods}

This study is a multi-centre cross-sectional descriptive study with consecutive sampling. Subjects were recruited from the outpatient dermatovenereology clinic of Dr Wahidin Sudirohusodo Hospital and Hasanuddin University Dermatovenereology Department's networking hospitals in Makassar between January 2017 and December 2018. Makassar is the capital city of South Sulawesi province in Indonesia. Written consent was obtained from all participants in the study. The study protocol was approved by the Research Ethics Committee of the Faculty of Medicine Hasanuddin University (No. 470/H4.8.4.5.31/PP36-KOMETIK/2018).

We evaluated cases for eligibility by confirming the diagnosis of syphilis based on the serological result using qualitative and quantitative RPR and TPHA commercial kit (RPR AIM Cat. No. E RPR 2 and TPHA AIM Cat. No. TPHA E 100). All syphilis cases were also screened for HIV infection using widely available screening kit SD Bioline ${ }^{\circledR}$ HIV 1/2 3.0 (Standard Diagnostics, Suwon City, South Korea). The cases were analyzed based on epidemiological features (gender, age, marital status), risk factors and clinical findings (ulcer, fever, lymphadenopathy, skin rash, condyloma lata), co-infection with other STI (HIV, genital herpes, gonorrhoea, condyloma acuminate, candidiasis), and stadium of the disease. We were able to generate meaningful summary statistics and tabulated the results. Statistical analyses were performed using Statistical Package for Social Science 20 software (SPSS Inc., Chicago, IL, USA) then reported as mean and percentage.

Table 1. Demographic data of the patients

\begin{tabular}{lcc} 
Variable & No. & $\%$ \\
\hline Age, yrs, mean \pm SD & $30.19 \pm 9.58$ & \\
Age Group & & 12.7 \\
$11-20$ & 10 & 51.8 \\
$21-30$ & 41 & 19 \\
$31-40$ & 15 & 11.4 \\
$41-50$ & 9 & 5.1 \\
$>51$ & 4 & 79.7 \\
\hline Gender & & 20.3 \\
Male & 63 & \\
Female & 16 & 44.3 \\
\hline Marital status & & 55.7 \\
$\quad$ Married & 35 & \\
Non-married & 44 & \\
\hline
\end{tabular}




\section{Results}

A total of 79 serologically confirmed syphilis cases were collected, and the results showed that $79.7 \%$ were male and $20.3 \%$ were female (giving a male: female ratio of $4: 1$ ), whose age was between 17 and 57 years (mean \pm standard deviation (SD), $30.19 \pm 9.58$ years) as shown in Table 1. The majority of subjects $(51.8 \%)$ were from $21-30$ age group and out of $55.7 \%$ who were not married, $65.9 \%$ were homosexual. Demographic data of the patients are shown in Table 1.

\section{Risk Factors and Clinical Manifestations}

Sexual intercourse was the major risk factor of contracting syphilis in the majority of patients including those of homosexual, bisex-

Table 2. Data on risk factors and clinical manifestations in the patients

\begin{tabular}{|c|c|c|}
\hline Variable & No. & $(\%)$ \\
\hline \multicolumn{3}{|l|}{ Risk Factors } \\
\hline Homosexual/ MSM & 38 & \\
\hline HIV-infected & 41 & \\
\hline IV drug user & 9 & \\
\hline Infected partner & 5 & \\
\hline \multicolumn{3}{|l|}{ History of Sexual Contact } \\
\hline Single partner & 5 & 6.4 \\
\hline Multiple partners & 43 & 54.5 \\
\hline Sexual worker & 10 & 12.7 \\
\hline Unknown & 21 & 26.4 \\
\hline \multicolumn{3}{|l|}{ Sexual Orientation } \\
\hline Heterosexual & 39 & 49.4 \\
\hline Homosexual/ MSM & 38 & 48.1 \\
\hline Bisexual & 2 & 2.5 \\
\hline \multicolumn{3}{|l|}{ Clinical Manifestations } \\
\hline Ulcer & 11 & \\
\hline Fever & 12 & \\
\hline Lymphadenopathy & 8 & \\
\hline Skin rash & 20 & \\
\hline Palmoplantar rash & 1 & \\
\hline Condyloma Lata & 0 & \\
\hline \multicolumn{3}{|l|}{ Co-infection with STIs } \\
\hline HIV & 41 & \\
\hline Genital Herpes & 4 & \\
\hline Gonorrhoea & 10 & \\
\hline Condyloma Acuminate & 27 & \\
\hline Candidiasis Vaginalis & 16 & \\
\hline \multicolumn{3}{|l|}{ Clinical Manifestations } \\
\hline Single & 20 & 25.3 \\
\hline Multiple & 9 & 11.4 \\
\hline Asymptomatic & 50 & 63.3 \\
\hline \multicolumn{3}{|l|}{ Stadium } \\
\hline Primary & 10 & 12.6 \\
\hline Secondary & 19 & 24.1 \\
\hline Latent & 50 & 63.3 \\
\hline
\end{tabular}


Table 3. Laboratory results of the patients

\begin{tabular}{ccc} 
Variable & No. & $\%$ \\
RPR & & 32.9 \\
$1: 4$ & 26 & 6.3 \\
$1: 8$ & 5 & 55.7 \\
$1: 16$ & 44 & 5.1 \\
$1: 32$ & 4 & \\
\hline TPHA & & 7.6 \\
$1: 20$ & 6 & 41.7 \\
$1: 40$ & 33 & 0 \\
$1: 80$ & 0 & 0 \\
$1: 160$ & 0 & 6.3 \\
$1: 320$ & 5 & 15.2 \\
$1: 640$ & 12 & 24.1 \\
$1: 1280$ & 19 & 5.1 \\
$1: 2560$ & 4 & \\
\hline HIV co-infection & & 51.9 \\
Positive & 41 & 48.1 \\
Negative & 38 & \\
\hline
\end{tabular}

ual and heterosexual orientation. Namely, of 63 male cases $(79.7 \%)$ diagnosed with syphilis, 38 $(48.1 \%)$ were homosexual/MSM, and of 41 cases of HIV-infected patients, 25 cases $(60.9 \%)$ were homosexual/MSM. Heterosexual patients who were co-infected with HIV had a history of contact with sex workers. An increase in the number of syphilis cases in heterosexuals was related to the history of sex worker contact. Whereas out of 16 female patients, in 9 cases they were sex workers, 1 case of a sex worker with a history of IV drug user, 1 case of IV drug user and in 5 cases they contracted syphilis from the partner who was infected.

Clinical manifestations including fever, ulcer, lymphadenopathy, skin rash were also assessed and tabulated. A total of 11 patients came with ulcers accompanied by lymphadenopathy and 10 (12.6\%) among them were serologically positive hence diagnosed with primary syphilis, secondary syphilis was diagnosed in 19 patients (24.1\%) with constitutional symptoms such as fever accompanied by rash on the skin and palmoplantar rash, and the remaining 50 patients (63.3\%) were asymptomatic thus considered as latent syphilis. In this study, we found 41 HIV coinfected patients with other STI diseases such as genital herpes, condyloma acuminate, candidiasis vaginalis, and gonorrhoea. A total of 20 patients showed a single clinical symptom, while 9 patients showed multiple or more than 1 clinical symptoms.

Of the 79 cases, syphilis was latent in 50 patients. It is likely that symptoms of syphilis were mild, non-specific and did not cause complaints, making it difficult to make an early diagnosis. Data on risk factors and clinical manifestations are shown in Table 2.

\section{Laboratory data}

Of 79 patients diagnosed with syphilis, RPR titers were $1: 16$ in 44 patients $(55.7 \%)$ and 4 patients $(5.1 \%)$ had higher titer $1: 32$. All syphilis cases were also screened for HIV infection in 41 HIV-infected patients, 26 of whom were MSM, 2 bisexual patients, 4 patients had sexual worker contact history. Laboratory data are shown in Table 3.

\section{Discussion}

All cases with diagnosis of syphilis were the subject of this study. Some subjects were co-infected with other STI diseases such as HIV, genital herpes, candidiasis, condyloma, or gonorrhea. The prevalence of syphilis has recently increased, hence more research is needed to improve health services in Makas- 
sar. In this study, of all 79 cases of syphilis, the majority were men $(79.7 \%)$ of whom $48.1 \%$ were homosexual/MSM, $2.5 \%$ were bisexual and $49.4 \%$ were heterosexual. The majority of transmission in heterosexual patients resulted from free sex and 5 female patients were infected by their (only one) partner. Syphilis is mostly diagnosed in men (51.8\%) and young adults between the ages of 21 and 30 years. Subjects who were not married accounted for $55.7 \%$. In 2014 the male population in the United States contributed to $90.8 \%$ of all cases of primary and secondary syphilis, the prevalence rates being highest at the age of 20 to 29 years. (11) The Centers for Disease Control and Prevention (CDC) reported that there was a rapid increase in the number of cases, with the largest increase in MSM and non-married men $60.2 \%$, with homosexual and bisexual orientation (12). These findings vary from studies in Norway which reported that as many as $70 \%$ of heterosexual men were infected by their partners or sex workers, while in female almost half of them were infected by their sole partners (13). It is generally known that syphilis is mostly transmitted through sexual contact which is the most common transmission mode (9). Most of the syphilis patients are asymptomatic and thus diagnosed as latent syphilis, so according to our findings in this study, the predominant finding is latent syphilis. Patients who present with complaints of genital ulcers, sometimes accompanied by enlarged lymph nodes, are diagnosed with primary syphilis. Furthermore, secondary syphilis is diagnosed as the initial stage of syphilis among symptomatic patients. Some co-infected patients with other STI diseases have been observed. The distribution of RPR ranges from 1: 4 to 1:32 and the majority of patients in this study were found to have titers 1:16 (55.7\%). HIV serology was positive in $51.9 \%$ of patients and 25 of them were MSM patients. Reported unprotected anal intercourse is increasing rapidly. Patients diagnosed with gonorrhoea, chlamydia or syphilis are more likely to be asymptomatic (14). Evaluation of recommendations for annual syphilis testing of HIV-positive MSM in the Netherlands revealed up to one-third of infections were asymptomatic and was detected by screening (15). Primary and secondary syphilis was mostly reported in the age group 15 to 19 and 20-39 in the Russian Federation and Kuala Lumpur, respectively $(9,13)$. In devel- oping countries, up to $90 \%$ incidence of primary and secondary syphilis is reported in young men aged 20-29 years, but since 2006 the situation has changed so the most frequently infected are those aged 35-59 years (16). Studies in the United States reported that MSM, heterosexual men and HIV co-infected women had a higher risk of being infected with syphilis. They revealed up to $50 \%$ of MSM, who were diagnosed with syphilis, were also co-infected with HIV and around $61.1 \%$ of primary and secondary syphilis occurred among MSM $(8,17)$. Studies in China have also shown that increased prevalence of syphilis were detected among MSM and HIV-infected populations (18). Studies in Brazil also revealed similar findings, namely the existence of strong relationships between male gender and MSM orientation with higher T. pallidum infection (19). Various studies have shown similar findings in which MSM populations, male and young adults were the dominant group diagnosed with syphilis. Proper monitoring and testing of these high-risk populations can help to keep the disease under control (1). In this study, most patients showed no symptoms at the time of serological diagnosis thus making the diagnosis of latent syphilis dominant. This descriptive study encourages screening for all high-risk STI patients, where syphilis and HIV co-infection are a crucial matter to be explained further to the patients, especially in terms of treatment and prognosis.

\section{Conclusion}

Our study showed there was a significant correlation between syphilis and an increased risk of HIV transmission in MSM groups. The higher number of cases of syphilis and HIV coinfection among MSM can increase transmission of both infections and should be considered a major risk factor for syphilis in Makassar.

\section{Abbreviations}

CDC - Centers for Disease Control and Prevention

FTA-ABS - Fluorescent treponemal antibody absorbed

HIV - Human immunodeficiency virus

IV - Intravenous

MSM - Men who have sexual relationships with other men 
RPR - Rapid plasma reagin

STI - Sexually transmitted infection

STBP - Surveilans terpadu biologi prilaku

SPSS - Statistical Package for Social Science

SD - Standard deviation

TPHA - Treponema pallidum haemagglutination TRUST - Toluidine red unheated serum test TPPA - Treponema pallidum particle agglutination

\section{References}

1. Mattei PL, Beachkofsky TM, Gilson RT, Wisco OJ. Syphilis: a reemerging infection. Am Fam Physician. 2012;86(5):433-40.

2. García-García L, Ariza-Megía MC, González-Escalada A, Alvaro-Meca A, Gil-Demiguel A, Gil-Prieto R. Epidemiology of syphilis-related hospitalisations in Spain between 1997 and 2006: a retrospective study. BMJ Open. 2011;1(2):e000270.

3. Wijesooriya NS, Rochat RW, Kamb ML, Turlapati P, Temmerman M, Broutet N, et al. Global burden of maternal and congenital syphilis in 2008 and 2012: a health systems modelling study. Lancet Glob Health. 2016;4(8):e525-33.

4. Braxton J, Carey D, Davis D, Flagg E, Footman A, Grier L, et al. Sexually transmitted disease surveillance 2014 [Internet]. Atlanta, Georgia: U.S. Department of Health and Human Services, Centers for Disease Control and Prevention National Center for HIV/ AIDS, Viral Hepatitis, STD, and TB Prevention Division of STD Prevention; 2014 [cited 2019 Aug 5]. Available from: https://www.cdc.gov/std/stats/archive/surv2014-print.PDF.

5. The Kirby Institute. HIV, viral hepatitis and sexually transmissible infections in Australia Annual Surveillance Reports 2016. Sydney: The Kirby Institute; 2016.

6. Stamm LV. Syphilis: re-emergence of an old foe. Microb Cell. 2016;3(9):363-70.

7. Kementerian Kesehatan Republik Indonesia. Surveilans terpadu biologi dan perilaku. Jakarta: Kementerian Kesehatan Republik Indonesia Dirjen Pengendalian Penyakit dan Penyehatan Lingkungan; 2011.

8. Yang B, Hallmark CJ, Huang JS, Wolverton ML, McNeese-Ward M, Arafat RR. Characteristics and risk of syphilis diagnosis among HIV-infected male cohort: a population-based study in Houston, Texas. Sex Transm Dis. 2013;40(12):957-63.
9. Wahab AA, Ramli MEA, Mustafa RAM, Lim GMW, Sahimi WNW, Husyairi H, et al. Sero-epidemiology of syphilis in a tertiary teaching hospital in Kuala Lumpur. Bangladesh J Med Sci [serial on the Internet]. 2018 [cited 2019 Aug 5];17(1):62-6. Available from: https:// www.banglajol.info/index.php/BJMS/article/ view/35282.

10. Ho EL, Lukehart SA. Syphilis: using modern approaches to understand an old disease. J Clin Invest. 2011;121(12): 4584-92.

11. Centers for Disease Control and Prevention. Sexually transmitted diseases surveillance 2017 [Internet]. 2017 [updated 2018 Oct 15; cited 2019 Aug 6]. Available from: https://www.cdc.gov/std/stats17/default.htm.

12. National Center for HIV/AIDS, Viral Hepatitis, STD and TP. Syphilis - CDC Fact Sheet [Internet]. 2015 [updated 2017 Jun; cited 2019 Aug 5]. Available from: https://www.cdc.gov/std/syphilis/Syphilis-June-2017.pdf.

13. Jakopanec I, Grjibovski AM, Nilsen $\varnothing$, Aavitsland P. Syphilis epidemiology in Norway, 1992-2008: resurgence among men who have sex with men. BMC Infect Dis. 2010;(10):105.

14. Mimiaga MJ, Helms DJ, Reisner SL, Grasso C, Bertrand T, Mosure DJ, et al. Gonococcal, chlamydia, and syphilis infection positivity among MSM attending a large primary care clinic, Boston, 2003 to 2004. Sex Transm Dis. 2009;36(8):507-11.

15. Branger J, van Der Meer JT, van Ketel RJ, Jurriaans $\mathrm{S}$, Prins JM. High incidence of asymptomatic syphilis in HIV-infected MSM justifies routine screening. Sex Transm Dis. 2009;36(2):84-5.

16. Clement ME, Okeke NL, Hicks CB. Treatment of syphilis: a systematic review. JAMA. 2014;312(18):1905-17.

17. Seña AC, Zhang XH, Li T, Zheng HP, Yang B, Yang LG, et al. A systematic review of syphilis serological treatment outcomes in HIV-infected and HIV-uninfected persons: rethinking the significance of serological non-responsiveness and the serofast state after therapy. BMC Infect Dis. 2015;15:479.

18. Sullivan PS, Hamouda O, Delpech V, Geduld JE, Prejean J, Semaille C, et al. Reemergence of the HIV epidemic among men who have sex with men in north America, western Europe, and Australia, 1996-2005. Ann Epidemiol. 2009;19(6):423-31.

19. Adolf R, Bercht F, Aronis ML, Lunardi LW, Schechter $M$, Sprinz E. Prevalence and risk factors associated with syphilis in a cohort of HIV positive individuals in Brazil. AIDS Care. 2012;24(2):252-8. 


\section{Sero-epidemiologija i faktori rizika sifilisa u Makasaru, Indonezija}

\section{Sažetak}

Uvod. Sifilis je infektivna bolest koju izaziva Treponema pallidum spirohete i uglavnom se prenosi seksualnim odnosom. Sifilis ima potencijal da izazove ozbiljne komplikacije i u tesnoj vezi je sa infekcijom HIV-om, zbog čega je sifilis veliki zdravstveni problem. U Indoneziji, pregledima visokorizičnih populacija koji su izvedeni 2007. i 2011. godine ustanovljeno je povećanje u rasprostranjenosti sifilisa, pogotovo kod homoseksualaca. Štaviše, u studijama su opisani faktori rizika za prenos HIV-a uključujući homoseksualne i heteroseksualne odnose, upotrebu droge intravenski i zaražene partnere. Cilj je bio utvrditi epidemiološke aspekte i faktore rizika za sifilis u Makasaru, kao i povezanost koinfekcije sa drugim seksualno prenosivim infekcijama. Materijal i metode. Ova studija je multicentrična, poprečnog preseka, deskriptivna sa konsekutivnim uzorkovanjem. Slučajevi su odabirani tako što je potvrđena dijagnoza na osnovu seroloških rezultata dobijenih pomoću RPR, TPHA i HIV skrining testa. Slučajevi su analizirani na osnovu: epidemioloških karakteristika, faktora rizika i kliničkih nalaza, koinfekcije sa drugim seksualno prenosivim infekcijama i stadijuma bolesti. Rezultati. Bilo je ukupno 79 serološki potvrđenih slučajeva sifilisa u periodu između januara 2017. i decembra 2018. godine u Makasaru, glavnom gradu provincije Južni Sulavesi, Indonezija. Od 63 ispitanika muškog pola (79,7\%), 38 $(48,1 \%)$ bili su homoseksualci a od 41 slučaja ispitanika zaraženih HIV-om, 25 (60,9\%) takođe su bili homoseksualci. Zaključak. Naša studija je pokazala da postoji značajna povezanost između sifilisa i povećanog rizika od prenosa HIV-a kod homoseksualnih grupa. Povećani broj sifilisa i HIV koinfekcije između homoseksualaca može povećati širenje obe infekcije i treba ga smatrati bitnim faktorom rizika za sifilis u Makasaru.

Ključne reči: Serodijagnoza sifilisa; Faktori rizika; Seroepidemiološke studije; Seksualno prenosive bolesti; Homoseksualnost muškaraca; Indonezija

Received 17.08.2019.

Accepted 20.08.2019. 